\title{
Rapid identification of capybara (Hydrochaeris hydrochaeris) using allele-specific PCR
}

\author{
Henrique-Silva, F.*, Cervini, M., Rios, WM., Lusa, AL., Lopes, A., Gonçalves, D., Fonseca, D., \\ Franzin, F., Damalio, J., Scaramuzzi, K., Camilo, R., Ferrarezi, T., \\ Liberato, M., Mortari, N. and Matheucci Jr., E. \\ Departamento de Genética e Evolução, Universidade Federal de São Carlos - UFSCar, \\ Rod. Washington Luiz, Km 235, CEP 13565-905, São Carlos, SP, Brazil \\ *e-mail: dfhs@power.ufscar.br \\ Received August 11, 2005 - Accepted February 10, 2006 - Distributed February 28, 2007
}

(With 1 figure)

The capybara is the largest rodent in the world and is widely distributed throughout Central and South America (Paula et al., 1999). It is an animal of economic interest due to the pleasant flavor of its meat and higher protein content in comparison to beef and pork meat. The hide, hair and fat also have economic advantages. Thus, as an animal with such high economic potential, it is the target of hunters, even though hunting capybara is prohibited by law in Brazil (Fauna Law, number 9.605/98).

Due to their similarities, capybara meat is easily confused with pork. This occurs due to the apprehension of the meat from hunters, as well as in some restaurants that serve capybara meat that was slaughtered illegally. In both cases, when the meat is confiscated, those responsible for the crimes claim it is pork, hindering the enforcement of the law.

Therefore, an effective method of identifying this meat is important both in terms of combating the predatory hunting of capybara and protecting the rights of consumers to know the origin of what they are consuming. The objective of the present work was to identify capybara meat using allele-specific primers through PCR (Polymerase Chain Reaction) and discriminate it in relation to other types of meat, especially pork.

To carry out the present work, oligonucleotides were constructed using the gene sequence alignments of Transthyretin (TTH1), Growth Hormone Receptor (GHR) and rRNA $12 \mathrm{~S}$ from the following animals: Hydrochaeris hydrochaeris (GHR AF433948.1; TTH1 AF433902.1; 12S U12454.1); Sus scrofa (GHR NM214254; TTH1 U16131; 12S AJ002189); Bos indicus (GHR AY053545; 12S AY337529.1); Equus cabalus (GHR AF392878.1; 12S AY584828), and Agouti paca (GHR AF433928; TTH1 AF433881.1; 12S AY093664.1). These 3 genes were previously used in phylogenetic studies on rodents (Rowe and Honeycutt, 2002). The sequences were aligned using the Multalin software (Corpet, 1998). After alignment, primers were selected that perfectly aligned with only the capybara sequences.

DNA from Hydrochaeris hydrochaeris; Sus scrofa; Bos indicus; Agouti paca; Equus caballus and Dasyprocta agouti was extracted from approximately $10 \mathrm{~mm}^{3}$ frag- ments of frozen meat using treatment with proteinase K, as described in (Sambrook et al., 1989). Basically, the meat fragments were incubated in $400 \mu \mathrm{L}$ buffer $(10 \mathrm{mM}$ Tris-HCl, pH:7.8; 5 mM EDTA; 0.5\% SDS) containing $400 \mu \mathrm{g}$ of. proteinase $\mathrm{K}$ at $65^{\circ} \mathrm{C}$ for 2 hours. After that, the solution was treated with an equal volume of phenolchloroform, and the DNA was purified from the aqueous phase by ethanol precipitation. Approximately $50 \mathrm{ng}$ of the DNA was used in amplification reactions containing $20 \mathrm{mM}$ Tris. $\mathrm{HCl} \mathrm{pH}$ 8.4; $50 \mathrm{mM} \mathrm{KCl} ; 1.5 \mathrm{mM} \mathrm{MgCl}$, $0.2 \mathrm{mM}$ dNTPs, 10 picomoles of each primer; $1 \mathrm{U}$ of Taq DNA polymerase (Invitrogen) and milli Q water to $25 \mu \mathrm{L}$. Triton X-100 (final $0.1 \%$ for TTH1 and $12 \mathrm{~S}$ genes) and DMSO (final 5\% for GHR gene) were also tested so as to obtain more efficient amplifications. Each reaction contained the primers from each gene together with a pair of control primers that amplify the ZFX/ZFY genes of mammals (Aasen and Medrano, 1990). The reactions were carried out in a PTC100 MJ Research thermocycler, using 30 cycles at the following temperatures: $94{ }^{\circ} \mathrm{C} 1$ minute, $60{ }^{\circ} \mathrm{C} 1$ minute and $72{ }^{\circ} \mathrm{C} 1$ minute. In the first cycle, denaturation was at $94{ }^{\circ} \mathrm{C}$ for 2 minute. The amplification products were analyzed in $1.5 \%$ agarose gel stained with ethidium bromide, together with a molecular weight marker (Ladder $1 \mathrm{~kb}$ plus, Invitrogen).

Using the primers displayed in Table 1, it was possible to amplify efficiently the DNA extracted from the above-mentioned animals (Figure 1). The pair of primers used as the control (ZFX/ZFY) enabled us to amplify approximately $450 \mathrm{bp}$ band in all DNA from the tested animals.

In addition to the pair of control primers, the amplification reactions contained a second pair that was specific to capybara which resulted in amplifying two fragments when using DNA from this animal. These primers generated fragments of 220, 290 and $330 \mathrm{bp}$ for TTH1, 12S and GHR, respectively. The pair of primers TTH1, while not having resulted in the positive amplification of horse, cow and pig DNA, resulted in a positive unexpected amplification for Dasyprocta agouti and Agouti paca. A possible explanation for this fact is the presence of sequence variants for this gene that 
Table 1. Primer sequences.

\begin{tabular}{lllc}
\hline \multicolumn{1}{c}{ Genes } & \multicolumn{1}{c}{ Forward Primer } & \multicolumn{1}{c}{ Reverse Primer } & Product Size \\
\hline TTH1 & TTTAAACTTCAAAAAGAACGAG & TAATCTATGCAGTTTGTCCCCT & $220 \mathrm{bp}$ \\
$12 \mathrm{~S}$ & ACATAAAAGTTCACATAACAAGAAC & TTATGTTCTTTGGTAAGAAAATGTA & $290 \mathrm{bp}$ \\
GHR & AAACATGGACATTTATGCCCAA & GGAGGTATAATCTGGGAGAGCC & $330 \mathrm{bp}$ \\
ZFX/ZFY & ATAATCACATGGAGAGCCACAAGCT & GCACTTCTTTGGTATCTGAGAAAGT & $450 \mathrm{bp}$ \\
\hline
\end{tabular}

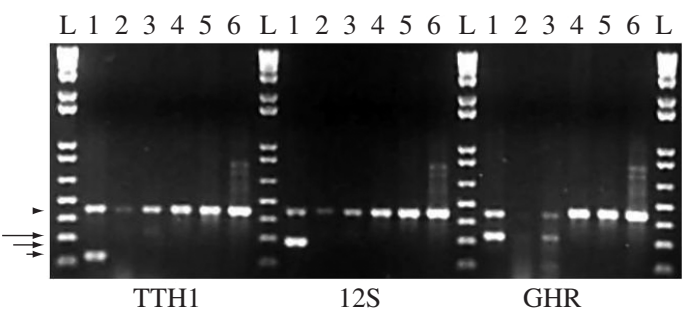

Figure 1. Results from the identification of capybara using allele-specific amplification. Electrophoresis in 1.5\% agarose gel showing in L, Ladder $1 \mathrm{~kb}$ plus (Invitrogen); 1-6, results for the DNA amplifications of $H$. hydrochaeris, D. agouti, A. paca, B. indicus, E. cabalus and S. scrofa. The arrow head indicates the control fragment of approximately $450 \mathrm{bp}$ (ZFX/ZFY). The other arrows, in decreasing order of size, indicate the amplified fragments of $330 \mathrm{bp}$ (GHR), $290 \mathrm{bp}(12 \mathrm{~S})$ and $220 \mathrm{bp}$ (TTH1).

allowed the annealing of the primers and consequent amplification. Nonetheless, this does not make the use of this pair unviable in the DNA discrimination of the rodents tested from horse, cow and pig DNA. Although DNA from various types of animals was used, the most relevant discrimination was that between capybara and pig, considering the similarities between the two types of meat and carcasses. Thus, the duplexes developed in the present work can be used effectively to discriminate the meat of these two animals, contributing to ecological studies as well as to combating predatory capybara hunt- ing, the illegal sale of capybara meat and the deceptive commercialization of capybara meat as being pork. The study also contributes toward the appreciation of authorized capybara raising that maintains strict sanitary control and faces disloyal competition on the part of meat from predatory hunting.

Acknowledgments - The authors would like to thank Fernando Magnani from the Parque Ecológico, Dr. Antônio Teixeira Vianna, São Carlos, for providing animal meat. They would also like to thank FAPESP for financial support.

\section{References}

AASEN, E. and MEDRANO, J.F., 1990. Amplification of the ZFY and ZFX genes for sex identification in humans, cattle, sheep and goats. Biotechnology (N Y), vol. 8, no. 12, p. 12791281 .

CORPET, F., 1988. Multiple sequence alignment with hierarchical clustering. Nucleic Acids Res., vol. 16, no. 22, p. 10881-10890.

PAULA, TA., CHIARINI-GARCIA, H. and FRANCA, L.R. 1999. Seminiferous epithelium cycle and its duration in capybaras (Hydrochoeris hydrochaeris). Tissue Cell, vol. 31, no. 3, p. 327-334.

ROWE, D.L. and HONEYCUTT, R.L., 2002. Phylogenetic Rel ationship, ecological correlates, and molecular evolution within the Cavioidea (Mammalia, Rodentia). Mol. Biol. Evol., vol. 19, no. 3 , p. 263-277.

SAMBROOK, J., FRITISH, E.F. and MANIATIS, T., 1989. Molecular cloning: a laboratory manual, 2nd edition. Cold Spring Harbor Laboratory Press, New York. 